\title{
Motion Tenderness Indicator
}

National Cancer Institute

\section{Source}

National Cancer Institute. Motion Tenderness Indicator. NCI Thesaurus. Code C154887.

An indication as to whether there are symptoms of motion tenderness. 